\title{
The possible role of ADP-ribosylation in sporulation and streptomycin production by Streptomyces griseus
}

\author{
Kozo Ochi, ${ }^{1 *}$ Andras Penyige ${ }^{2}$ and Gyorgy Barabas $^{2}$ \\ ${ }^{1}$ National Food Research Institute, 2-1-2 Kannondai, Tsukuba, Ibaraki 305, Japan \\ ${ }^{2}$ Institute of Biology, University Medical School, H-4012 Debrecen, Hungary
}

(Received 20 January 1992; revised 7 April 1992; accepted 1 May 1992)

\begin{abstract}
Mutants resistant to 3-aminobenzamide, a known inhibitor of ADP-ribosyltransferase, were obtained from Streptomyces griseus IFO 13189, a streptomycin-producing strain. One (strain no. 4), which had significantly reduced ADP-ribosyltransferase activity, was analysed in detail. Mutant 4 displayed a conditional phenotype with respect to cultivation temperature. At $30^{\circ} \mathrm{C}$, it exhibited severely reduced ability to produce aerial mycelium (on solid medium) and submerged spores and streptomycin (in liquid culture), but this ability was fully restored at $25^{\circ} \mathrm{C}$. The mutant produced A-factor normally, regardless of cultivation temperature, and exhibited normal ability to accumulate ppGpp intracellularly. SDS-PAGE analyses of cellular proteins labelled by ${ }^{32} P \mid N A D$ revealed that an ADP-ribosylated protein with a molecular size of $44 \mathrm{kDa}$, which appeared in sporulating cultures of the parent strain, was missing from the mutant grown at the non-permissive temperature $\left(30{ }^{\circ} \mathrm{C}\right)$. Genetic analysis showed that the $a b a$ mutation conferring resistance to 3-aminobenzamide was tightly linked to the altered phenotype. Failure to ADP-ribosylate certain cellular protein(s), presumably due to the $a b a$ mutation, may be responsible for impaired differentiation in this mutant.
\end{abstract}

\section{Introduction}

ADP-ribosylation is a two-step enzymic reaction. First, NAD is hydrolysed by NAD-glycohydrolase to release nicotinamide and adenosinediphosphoribose (ADPR), then ADPR is bound to specific acceptor proteins by the action of ADP-ribosyltransferase (ADPRT) (reviewed by Skorko, 1982; Ueda \& Hayaishi, 1985). Mono-ADPribosylation can be detected in prokaryotes and eukaryotes, while poly-ADP-ribosylation occurs only in eukaryotes (Ueda \& Hayaishi, 1985). ADP-ribosylation may inactivate proteins; moreover, the modified proteins may later be activated by enzymic de-ADP-ribosylation. These processes play a significant role in various biologically important events such as DNA repair, modification of RNA polymerase, inhibition of protein synthesis, regulation of cell proliferation and differentiation (Ferro et al., 1983; Tanigawa et al., 1983; Lucas et

\footnotetext{
* Author for correspondence. Fax 0298387996.
}

Abbreviations: 3-ABA, 3-aminobenzamide; ADPRT, ADPribosyltransferase. al., 1984; Payne et al., 1985; reviewed by Ueda \& Hayaishi, 1985; Lai, 1986; Miwa \& Sugimura, 1990). Most of the data available are from eukaryotic organisms. Our knowledge of the presence and role of ADPRT enzymes in prokaryotes is in its infancy.

T4 and N4 phage infections in Escherichia coli are known to result in ADP-ribosylation of the $\alpha$-subunit of RNA polymerase (Skorko, 1982). Nitrogenase activity in Rhodospirillum rubrum and Azospirillum lipoferum is regulated by ADP-ribosylation of the iron subunit of the enzyme (Pope et al., 1985; Hartmann et al., 1986). Two cytoplasmic proteins of Pseudomonas maltophilia are reported to be ADP-ribosylated (Edmonds et al., 1989). After ADPRT activity was reported in Streptomyces, first in S. griseus and later in other Streptomyces species, attempts were made to elucidate its physiological role (Barabas et al., 1986, 1988). In this communication we compare the ADPRT activity in parent and mutant strains of $S$. griseus, and discuss the possible role of this enzyme in the physiological regulation of sporulation and antibiotic production. Genetic aspects of the potential significance of ADP-ribosylation in microbial differentiation are stressed. 


\section{Methods}

Chemicals. 3-Aminobenzamide (3-ABA) was purchased from Nakarai Tesque, Kyoto, Japan. [adenine- $\left.2,8-{ }^{3} \mathrm{H}\right] \mathrm{NAD}$ and [adenylate${ }^{32}$ P]NAD were from Amersham and ICN Biomedicals, respectively.

Strains and preparation of mutants. Streptomyces griseus IFO 13189, a wild-type, prototrophic, streptomycin-producing strain, was provided by the Institute of Fermentation, Osaka, Japan. The spontaneous 3aminobenzamide-resistant mutants were obtained as colonies that grew within $14 \mathrm{~d}$ after wild-type spores were spread on GYM agar (see below) containing $80 \mathrm{~mm}$-3-ABA. The parent strain was able to grow, although slowly, with $50 \mathrm{~mm}-3-\mathrm{ABA}$, but its growth was completely suppressed with $80 \mathrm{~mm}$. The resistant clones were purified by single colony isolation.

To obtain auxotrophic mutants spores were treated with $\mathrm{N}$-methyl$N^{\prime}$-nitro- $N$-nitrosoguanidine (Ochi, 1990a). Auxotrophs were determined by replica plating on synthetic medium II (Ochi, 1990a) with or without appropriate requirements. The spontaneous reversion rate for each single auxotrophic requirement was less than $10^{-8}$.

Media. Sporulation medium contained (per litre): soluble starch, $20 \mathrm{~g}$; yeast extract, $4 \mathrm{~g}$; $\mathrm{MgSO}_{4} .7 \mathrm{H}_{2} \mathrm{O}, 0.5 \mathrm{~g} ; \mathrm{CaCl}_{2}, 50 \mathrm{mg}$; $\mathrm{ZnSO}_{4} .7 \mathrm{H}_{2} \mathrm{O}, 30 \mathrm{mg} ; \mathrm{FeSO}_{4} .7 \mathrm{H}_{2} \mathrm{O}, 25 \mathrm{mg} ; \mathrm{CuSO}_{4} .5 \mathrm{H}_{2} \mathrm{O}, 16 \mathrm{mg}$; and $\mathrm{MnSO}_{4} .4 \mathrm{H}_{2} \mathrm{O}, 12 \mathrm{mg}$ (adjusted to $\mathrm{pH} 7.0$ with $\mathrm{NaOH}$ ). GYM medium contained (per litre): glucose, $4 \mathrm{~g}$; yeast extract, $4 \mathrm{~g}$; malt extract, $10 \mathrm{~g}$; peptone (NZ-amine, type $\mathrm{A}$ ), $1 \mathrm{~g} ; \mathrm{NaCl}, 2 \mathrm{~g}$ (adjusted to pH 7.2 with $\mathrm{NaOH}$ ). GYM agar contained $2 \%$ agar in addition to the above components. Synthetic medium II and starch-polypeptone-yeast extract (SPY) medium have been described previously (Ochi, 1987a). Since 3-ABA is heat-stable, media containing it were autoclaved with all components present.

Growth conditions. A spore suspension was used to inoculate SPY medium, and the culture was incubated at $30^{\circ} \mathrm{C}$ as described by Ochi (1987a). After $2 \mathrm{~d}$, cells were harvested by centrifugation, washed twice with $100 \mathrm{ml}$ saline, and suspended in the original volume of saline. Washed cells $(1 \mathrm{ml})$ were added to sporulation medium $(50 \mathrm{ml}$ in a $250 \mathrm{ml}$ flask) and then cultured on a rotary shaker $(230$ r.p.m.) at the temperature indicated.

Fusion of protoplasts. Protoplast fusion was performed as described previously (Ochi, 1990a). The frequency of mycelium regeneration from protoplasts was about $10^{-3}$. The frequency of recombinants, given as the ratio of prototrophic colonies growing on minimal regeneration medium to the total number of viable colonies on supplemented regeneration medium, was about $3 \times 10^{-3}$. Prototrophic recombinants selected directly on minimal regeneration medium were purified by single colony isolation and then tested for their ability to form aerial mycelium (on GYM agar) and streptomycin (in SPY medium) at $30^{\circ} \mathrm{C}$.

Assay of submerged spores. Sonication-resistant spore titres were determined by direct counting of spores, using phase contrast optics after sonication of cultured broth for $3 \mathrm{~min}$. Spores, but not mycelial fragments, were visible as phase bright objects

Assay of streptomycin and A-factor. These were determined by bioassay (Ochi, 1987a).

Enzyme assays. NAD-glycohydrolase was assayed as described previously (Ochi, 1987a), except that NAD was used as substrate instead of NADP. To assay ADP-ribosyltransferase (ADPRT), crude extract was obtained by sonic disruption (approx. $1 \mathrm{~min}$ at $0^{\circ} \mathrm{C}$ ) of cells suspended in $10 \mathrm{mM}$-MOPS buffer (pH 7.2) containing 2 mM-PMSF. Cells were centrifuged $(10000 \mathrm{~g})$ at $4^{\circ} \mathrm{C}$ for $20 \mathrm{~min}$. The supernatant thus obtained was used as a 'crude extract', which provided not only the enzyme protein but also substrate proteins to be ADP-ribosylated. It contained 1.2 to $2.4 \mathrm{mg}$ protein per $\mathrm{ml}$. The reaction conditions described by Penyige et al. (1990) were modified as follows. A $100 \mu \mathrm{l}$ sample of crude extract was suspended in $100 \mu \mathrm{l}$ of a solution containing $25 \mathrm{~mm}$-potassium phosphate buffer (pH 7.0), $10 \mathrm{~mm}$-DTT, $0.5 \mathrm{mM}-\mathrm{MgCl}_{2}, 20 \mathrm{mM}-\mathrm{KF}, \quad 0.1 \mathrm{mM}-\mathrm{CaCl}_{2}$ and $30 \mu \mathrm{M}$-[adenine$\left.2,8-{ }^{3} \mathrm{H}\right] \mathrm{NAD}$ ( $37 \mathrm{kBq}$, as a donor of ADP-ribose). Reaction mixtures were incubated at the indicated temperature for $20 \mathrm{~min}$ before $200 \mu \mathrm{l}$ ice-cold $10 \%(\mathrm{w} / \mathrm{v})$ TCA was mixed in. After $30-60 \mathrm{~min}$ at $0{ }^{\circ} \mathrm{C}$, the suspensions were collected on membrane filters (Millipore, $0.45 \mu \mathrm{m}$ ), which were then washed with $5 \mathrm{ml}$ ice-cold $5 \%(\mathrm{w} / \mathrm{v})$ TCA. Radioactivity on the filters was measured with a liquid scintillation counter. The specific activity of ADPRT is expressed as the amount (d.p.m.) of radioactivity incorporated into acid-precipitable material per mg protein per min.

To obtain autoradiograms of ADP-ribosylated proteins, $30 \mu \mathrm{M}$ [adenylate- ${ }^{32}$ P]NAD $(37 \mathrm{kBq})$ was used instead of [adenine-2,8${ }^{3} \mathrm{H}$ ]NAD. SDS-PAGE was carried out as reported by Penyige $e t$ al. (1990). The gel was dried and exposed to X-ray film for $8 \mathrm{~d}$ at $-80^{\circ} \mathrm{C}$.

Alkaline hydrolysis of ${ }^{32} P$-labelled proteins. A crude extract was prepared from parent-strain mycelium harvested in late $(48 \mathrm{~h})$ growth phase as described above. One $\mathrm{ml}$ reaction mixture containing $30 \mu \mathrm{M}$ [adenylate- ${ }^{32} \mathrm{P}$ ]NAD $(9.25 \mathrm{MBq})$ was incubated at $35^{\circ} \mathrm{C}$ for $20 \mathrm{~min}$. Then proteins were precipitated by adding $1 \mathrm{ml}$ of $20 \%$ TCA. After 30 min at $0{ }^{\circ} \mathrm{C}$, then $10 \mathrm{~min}$ at $80^{\circ} \mathrm{C}$ (to redissolve lipids and nucleic acids), the precipitated proteins were collected by centrifugation at $10000 \mathrm{~g}$ for $20 \mathrm{~min}$ at $4{ }^{\circ} \mathrm{C}$. The pellet was washed once with ice-cold $10 \%(\mathrm{w} / \mathrm{v})$ TCA, and then twice with $70 \%(\mathrm{v} / \mathrm{v})$ ethanol. It was resuspended in a small amount (approx. $3 \mathrm{ml}$ ) of $10 \mathrm{~mm}-\mathrm{Tris} / \mathrm{HCl}$ buffer $(\mathrm{pH} \mathrm{7.0})$ containing $6 \mathrm{M}$-guanidine. $\mathrm{HCl}$ to solubilize proteins. For alkaline hydrolysis of ${ }^{32} \mathrm{P}$-labelled proteins (Jouanneau et al., 1989), portions $(1 \mathrm{ml})$ of the protein suspension were incubated in $0.1 \mathrm{M}-\mathrm{KOH}$ at $27^{\circ} \mathrm{C}$ or $37^{\circ} \mathrm{C}$ for $3 \mathrm{~h}$. At the end of the incubation, proteins were precipitated with excess perchloric acid (which also removes $\mathrm{K}^{+}$) at $0{ }^{\circ} \mathrm{C}$. After $30 \mathrm{~min}$, the samples were centrifuged at $12000 \mathrm{~g}$ for $10 \mathrm{~min}$ at $4{ }^{\circ} \mathrm{C}$, and the supernatants were concentrated under high vacuum to $200 \mu \mathrm{l}$. After further centrifugation $(12000 \mathrm{~g}), 20 \mu \mathrm{l}$ portions of the supernatant solutions were applied to silica gel TLC plates $\left(60 \mathrm{~F}_{254}\right.$, Merck). Reference samples (10 nmol each) of NAD, ADP-ribose, ADP and AMP were also applied in one spot. The chromatograms were developed with $n$-butanol:acetone:acetic acid:5\% (w/v) ammonia : water $(9: 7: 5: 5: 2)$ for $3 \mathrm{~h}$. The standards were detected by their UV absorption, and the chromatogram was exposed to $\mathrm{X}$-ray film with an intensifying screen for $8 \mathrm{~h}$ at $-80^{\circ} \mathrm{C}$.

Assay of nucleotide pools and intracellular 3-ABA. Intracellular concentrations of GTP and guanosine $5^{\prime}$-diphosphate $3^{\prime}$-diphosphate (ppGpp) were assayed by HPLC as described earlier (Ochi, 1986b, $1987 a$ ). Intracellular concentrations of 3-ABA were determined as follows. Cells $(10 \mathrm{ml}$ portions) grown in $50 \mathrm{ml}$ GYM medium containing various amounts of 3-ABA were rapidly collected on a filter paper (diameter $9 \mathrm{~cm}$, no. 2, Toyo Roshi Co.) and washed with $200 \mathrm{ml}$ $0 \cdot 1 \mathrm{M}-\mathrm{LiCl}$. The filter was then immediately placed upside down in a Petri dish containing $10 \mathrm{ml} 1 \mathrm{M}$-formic acid; the entire collection procedure was completed within $30 \mathrm{~s}$. A separate $40 \mathrm{ml}$ sample was used to determine the dry cell weight. After $1 \mathrm{~h}$ incubation in a cold room, a sample for assay by HPLC was prepared as described previously (Ochi, 1986b). The 3-ABA in the extract was determined by HPLC as follows. A $50 \mu \mathrm{l}$ sample (equivalent to about $0.2 \mathrm{mg}$ dry cell weight) was applied to a column (Hibar LiChlospher $100 \mathrm{RP}-18,5 \mu \mathrm{m}$, $4 \times 250 \mathrm{~mm}$, Merck) developed with a solution containing $5 \%(\mathrm{v} / \mathrm{v})$ methanol, $5 \%(\mathrm{v} / \mathrm{v})$ acetonitrile, $1 \%(\mathrm{v} / \mathrm{v})$ tetrahydrofuran, and $0.025 \%$ phosphoric acid at a flow rate of $1 \mathrm{ml}$ per min. Absorbance was measured at $235 \mathrm{~nm} ; 3-\mathrm{ABA}$ was eluted at a retention time of $4.2 \mathrm{~min}$. The intracellular concentration (mM) of 3-ABA was calculated assuming that $1 \mathrm{mg}$ dry cell weight represented $3.3 \mu \mathrm{l}$ intracellular water (Ochi, 1987b). 


\section{Results and Discussion}

\section{Isolation of 3-ABA-resistant mutants}

The possible significance of ADP-ribosylation of cellular protein(s) in sporulation of certain $S$. griseus strains has been suggested by Barabas et al. (1988). In preliminary experiments, only slight growth inhibition of $S$. griseus was observed on GYM agar containing $50 \mathrm{~mm}-3-$ aminobenzamide (3-ABA), whereas aerial mycelium formation (and thus sporulation) was severely depressed. 3-ABA, an analogue of nicotinamide, is a potent inhibitor of poly(ADP-ribosyl)transferase (Purnell \& Whish, 1980; Banasik et al., 1992), which plays a central role in ADP-ribosylation reactions in eukaryotes. Although Banasik et al. (1992) showed benzamide and its derivatives to be weak inhibitors of mono(ADP-ribosyl)transferase from hen heterophils, Penyige et al. (1990) have demonstrated that 3-ABA strongly inhibits ADPribosylation in $S$. griseus. Therefore, some 3-ABAresistant mutants might have an altered ADPRT affecting sporulation. To assess this possibility, we isolated and analysed mutants. Four colonies (1, 4, 5 and 7) of S. griseus 13189 that developed spontaneously on

Table 1. Intracellular 3-ABA concentration in cells cultured in the presence of 3- $A B A$

Strains were grown at $30^{\circ} \mathrm{C}$ for $12 \mathrm{~h}$ (mid-exponential phase) in GYM medium, filtered and transferred to the same volume of fresh GYM medium containing various amounts of 3-ABA; incubation was then continued for $5 \mathrm{~h}$. The 3-ABA concentration was assayed as described in Methods.

\begin{tabular}{ccc}
\hline & \multicolumn{2}{c}{ Intracellular concentration (mM) } \\
\cline { 2 - 3 }$(\mathrm{mM})$ & Parent & Mutant 4 \\
\hline 20 & 0.09 & 0.10 \\
50 & 0.37 & 0.32 \\
80 & 0.52 & 0.56 \\
\hline
\end{tabular}

GYM agar containing $80 \mathrm{~mm}-3-\mathrm{ABA}$ were selected randomly. These all exhibited severely reduced ability to form aerial mycelium when cultured at $30^{\circ} \mathrm{C}$. Their ability to produce A-factor was normal. The mutants grew as well as the parent strain in sporulation medium or SPY medium, but somewhat slowly in synthetic medium. Mutant no. 4 was used for most further analyses since it exhibited the highest resistance to 3-ABA (up to $100 \mathrm{mM}$ ).

Concentrations of 3-ABA within cells grown in the presence of the drug (Table 1) were roughly proportional to, but far lower than, those outside the cells; presumably 3-ABA was taken up through passive, rather than active, transport. The similar intracellular 3-ABA concentrations of the parent and mutant 4 imply that the mutation had not altered the transport system. The intracellular 3ABA concentration in the presence of $80 \mathrm{~mm}-3-\mathrm{ABA}$ was about $0.5 \mathrm{~mm}$ (Table 1), at which concentration the ADPRT activity of $S$. griseus is known from in vitro experiments to be inhibited by $50-60 \%$ (Penyige et al., 1990). Thus, the observed growth inhibitory effect of 3$\mathrm{ABA}$ in the parent strain could be due, at least in part, to its action on ADPRT.

\section{Characterization of the mutants}

The parent strain began to produce sonication-resistant spores after incubation for $24 \mathrm{~h}$ at $30^{\circ} \mathrm{C}$ in sporulation medium, and almost all cells $(>80 \%)$ were present as spores at $48 \mathrm{~h}$. However, the mutant produced 30 -fold less spores (Table 2), and was impaired in producing streptomycin. Strikingly, the ability of mutant 4 to produce submerged spores or streptomycin was temperature-dependent; when the incubation temperature was lowered to $25^{\circ} \mathrm{C}$ both abilities were completely restored (Table 2). A-factor was produced normally $(0 \cdot 4-1 \mu \mathrm{g}$ $\mathrm{ml}^{-1}$ ) regardless of cultivation temperature. The ability to produce aerial mycelium on surface culture was also completely restored at $25^{\circ} \mathrm{C}$. Mutant strains 1,5 and 7

Table 2. Sporulation and streptomycin production by parent and mutant strains in liquid culture

Data represent mean values from three independent experiments. There was no marked difference in biomass between parent and mutant strains $\left(2.5-3.1 \mathrm{mg}\right.$ dry weight $\mathrm{ml}^{-1}$ in sporulation medium, $6.8-7.7 \mathrm{mg}$ dry weight $\mathrm{ml}^{-1}$ in SPY medium).

\begin{tabular}{|c|c|c|c|c|c|c|}
\hline \multirow[b]{3}{*}{ Strain } & \multicolumn{2}{|c|}{ Sonication-resistant spores $\mathrm{ml}^{-1 *}$} & \multicolumn{4}{|c|}{ Streptomycin produced $\left(\mu \mathrm{g} \mathrm{ml}^{-1}\right) \dagger$} \\
\hline & \multirow[t]{2}{*}{$30^{\circ} \mathrm{C}$} & \multirow[t]{2}{*}{$25^{\circ} \mathrm{C}$} & \multicolumn{2}{|c|}{$30^{\circ} \mathrm{C}$} & \multicolumn{2}{|c|}{$25^{\circ} \mathrm{C}$} \\
\hline & & & $2 \mathrm{~d}$ & $3 d$ & $2 \mathrm{~d}$ & $3 d$ \\
\hline Parent (13189) & $3 \times 10^{8}$ & $5 \times 10^{8}$ & 83 & 95 & 41 & 132 \\
\hline Mutant 4 & $1 \times 10^{7}$ & $4 \times 10^{8}$ & 0 & 0 & 50 & 122 \\
\hline Mutant 7 & $1 \times 10^{8}$ & $2 \times 10^{8}$ & 8 & 40 & 42 & 97 \\
\hline
\end{tabular}

* Cells were grown in sporulation medium for $3 \mathrm{~d}$ at the indicated temperature.

+ Cells were grown in SPY medium for $2 \mathrm{~d}$ or $3 \mathrm{~d}$ at the indicated temperature. 
also showed this conditional phenotype for aerial mycelium formation, submerged spore formation, and streptomycin production, but the restoration at $25^{\circ} \mathrm{C}$ was incomplete. The impaired ability of mutant 4 to produce aerial mycelium at $30^{\circ} \mathrm{C}$ was not restored by the addition of decoyinine, adenine, guanine, nicotinamide, citrulline, ornithine or calcium chloride at any concentration tested $(0 \cdot 1-10 \mathrm{~mm})$.

Aerial mycelium formation by mutant 4 at $25^{\circ} \mathrm{C}$ showed an increased sensitivity to nutrients; adding $1 \%$ Casamino acids completely suppressed the development of aerial mycelium in mutant 4 but not in the parent strain.

\section{ADPRT activity}

To relate the altered phenotype to ADPRT function we measured the activity of the enzyme, together with that of NAD-glycohydrolase, which is presumably indirectly involved in ADP-ribosylation reactions. Mutants 4 and 7 grown at the non-permissive temperature $\left(30^{\circ} \mathrm{C}\right)$ both had substantially reduced ADPRT activity, with the larger decrease in mutant 4 (Table 3). The NADglycohydrolase activity in the mutants was also lower than in the parent, but the reduction was not so severe. ADPRT activity was compared in the parent and mutant 4 cells grown at permissive and non-permissive temperatures. Much less activity was detected in cells grown at $25^{\circ} \mathrm{C}$ than in cells grown at $30^{\circ} \mathrm{C}$ (Table 4). Unexpectedly, mutant 4 grown at $25^{\circ} \mathrm{C}$ had less ADPRT activity than the parent strain grown under similar conditions.

\section{ADP-ribosylation of cellular proteins}

Previous investigations (Barabas et al., 1988; Penyige et al., 1990) with another $S$. griseus strain (52-1) demonstrated that several membrane proteins are labelled enzymically during incubation with $\left[{ }^{32} \mathrm{P}\right]$ NAD. We used the same method to detect ADP-ribosylation of proteins in the parent and mutant strains, except that 'crude extract' was employed instead of a membrane preparation as the source of enzyme and of substrate proteins. The results of SDS-PAGE analyses of labelled cellular proteins are shown in Fig. 1. A $44 \mathrm{kDa}$ protein (band A) appears in sporulating cultures ( $48 \mathrm{~h}$ age) of the parent strain grown at $30^{\circ} \mathrm{C}$ but is missing from similar cultures of mutants 4 and 7. Two other labelled proteins with molecular sizes of 39 and $37 \mathrm{kDa}$ (bands $\mathrm{B}$ and C) were present in $48 \mathrm{~h}$ cultures, but appeared also in mutants 4 and 7; however the extent of labelling was different from the parent strain. A similar experiment with crude extracts from cells grown at the permissive temperature $\left(25^{\circ} \mathrm{C}\right)$ failed to give an informative autoradiogram,
Table 3. Intracellular NAD-glycohydrolase and ADPRT activity in parent and mutant strains grown in sporulation medium at $30^{\circ} \mathrm{C}$

Data are mean values from two independent experiments.

\begin{tabular}{|c|c|c|c|c|c|}
\hline \multirow[b]{3}{*}{ Strain } & \multicolumn{5}{|c|}{ Specific activity at various times (h) } \\
\hline & \multicolumn{3}{|c|}{$\begin{array}{c}\text { NAD- } \\
\text { glycohydrolase } \\
{\left[\mathrm{U}^{\left.(\mathrm{mg} \text { protein })^{-1}\right]^{*}}\right.}\end{array}$} & \multicolumn{2}{|c|}{$\begin{array}{c}\text { ADPRT } \dagger \\
\text { [d.p.m. }{ }_{(\mathrm{mg} \text { protein })^{-1}} \\
\left.\mathrm{~min}^{-1}\right]\end{array}$} \\
\hline & 12 & 24 & 48 & 24 & 96 \\
\hline Parent (13189) & $8 \cdot 2$ & $19 \cdot 4$ & $9 \cdot 6$ & 11270 & 18000 \\
\hline Mutant 4 & $4 \cdot 4$ & $9 \cdot 2$ & $7 \cdot 5$ & 3150 & 3800 \\
\hline Mutant 7 & 6.9 & $13 \cdot 5$ & $7 \cdot 3$ & 5400 & 8570 \\
\hline
\end{tabular}

* One unit is the amount of enzyme that catalyses the decomposition of $1 \mu \mathrm{mol}$ of NAD per min.

+ Reaction at $34^{\circ} \mathrm{C}$.

Table 4. Effect of culture temperature on ADPRT activity in $S$. griseus mycelium

Strains were grown in SPY medium at $30^{\circ} \mathrm{C}$ for $36 \mathrm{~h}$ or at $25^{\circ} \mathrm{C}$ for $42 \mathrm{~h}$. ADPRT was assayed as in Table 3, except that the reaction was carried out at $25^{\circ} \mathrm{C}$ as well as at $34^{\circ} \mathrm{C}$.

\begin{tabular}{|c|c|c|c|}
\hline \multirow[b]{2}{*}{ Strain } & \multicolumn{2}{|c|}{ Temperature used for } & \multirow{2}{*}{$\begin{array}{c}\text { Specific activity* } \\
\text { [d.p.m. }(\mathrm{mg} \text { protein })^{-1} \\
\left.(\mathrm{~min})^{-1}\right]\end{array}$} \\
\hline & Growth & $\begin{array}{l}\text { Enzyme } \\
\text { assay }\end{array}$ & \\
\hline Parent (13189) & $\begin{array}{l}30 \\
25\end{array}$ & $\begin{array}{l}34 \\
25 \\
34 \\
25\end{array}$ & $\begin{array}{l}6500 \pm 310 \dagger \\
5770 \pm 200 \\
1290 \pm 310 \\
1560 \pm 270\end{array}$ \\
\hline Mutant 4 & $\begin{array}{l}30 \\
25\end{array}$ & $\begin{array}{l}34 \\
25 \\
34 \\
25\end{array}$ & $\begin{array}{r}2170 \pm 120 \\
2750 \pm 210 \\
740 \pm 120 \\
870 \pm 200\end{array}$ \\
\hline
\end{tabular}

* Values are mean of two determinations \pm SD.

† ADP-ribose incorporation was calculated to be $0.61 \mathrm{pmol}(\mathrm{mg}$ protein) $)^{-1} \min ^{-1}$.

apparently because of lower enzyme activity. Although the altered ADP-ribosylation patterns might have resulted simply from the absence or decreased amount of proteins available for ADP-ribosylation, no difference was observed between protein bands of parent and mutant strains in SDS-PAGE gels stained with Coomassie Blue (data not shown).

\section{Identification of labelled modifying group}

We attempted to identify the labelled modifying group by subjecting a preparation of ${ }^{32} \mathrm{P}$-labelled proteins to alkaline treatment. When ${ }^{32} \mathrm{P}$-labelled proteins prepared as described above from a sporulating culture of the parent strain were incubated under alkaline conditions 


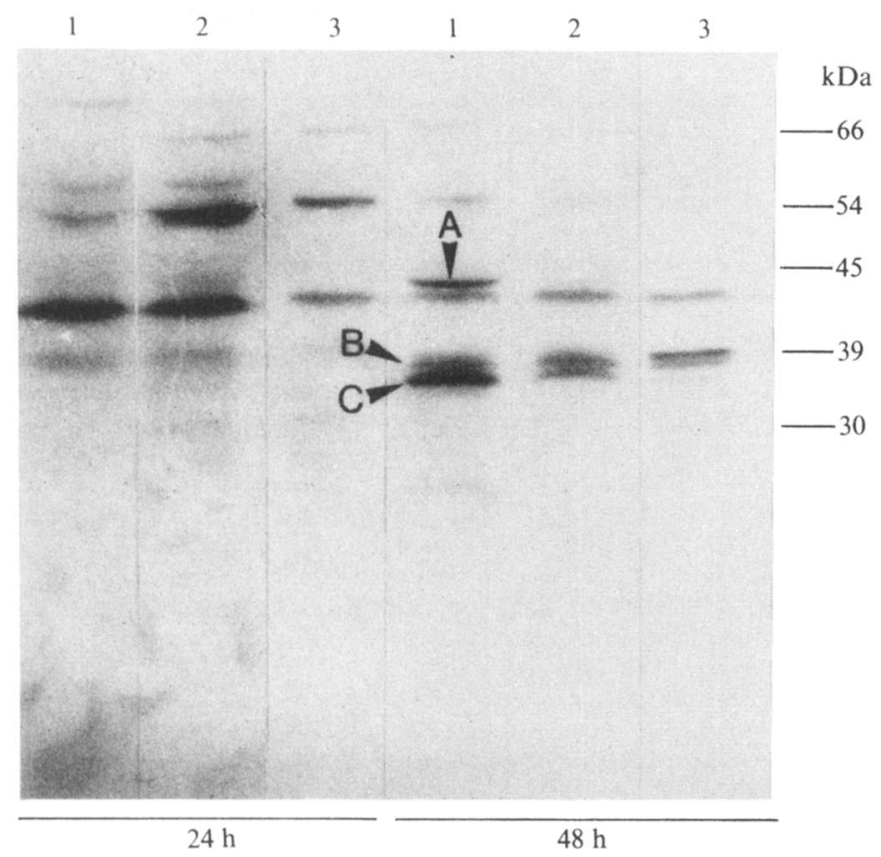

Fig. 1. Autoradiogram of an SDS-PAGE gel on which ADPribosylated proteins of $S$. griseus strains were separated. Crude extracts from cells grown in sporulation medium at $30^{\circ} \mathrm{C}$ to early $(24 \mathrm{~h})$ or late $(48 \mathrm{~h})$ growth phase were incubated at $34^{\circ} \mathrm{C}$ for $20 \mathrm{~min}$ with [adenylate${ }^{32} \mathrm{P}$ NNAD. Equivalent amounts of protein from the assay mixtures were analysed by SDS-PAGE. Positions of molecular mass standards are shown at the right hand side. Lanes: 1 , parent strain; 2 , mutant $4 ; 3$, mutant 7. A, B and C in the figure indicate the labelled proteins that appeared only in the late growth phase.

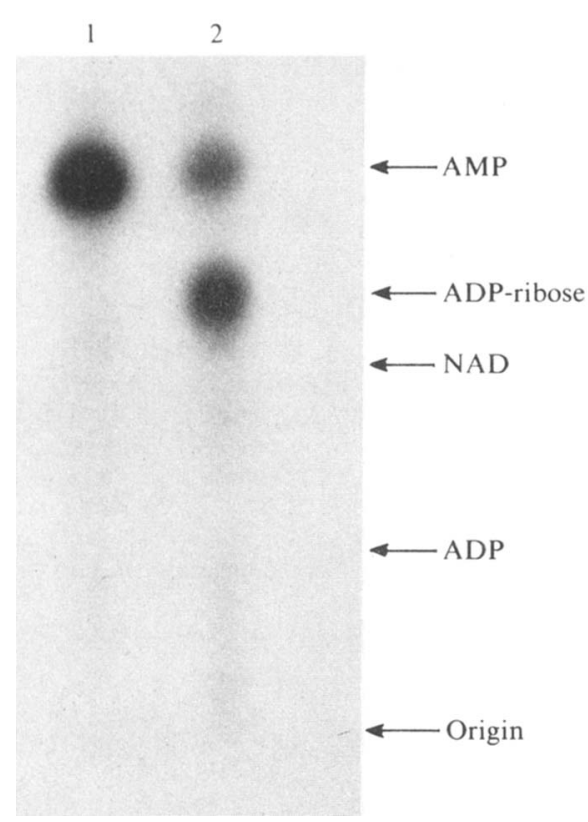

Fig. 2. TLC analysis and autoradiography of alkaline hydrolysate of proteins of $S$. griseus 13189 previously incubated with [ $\left.{ }^{32} \mathrm{P}\right]$ NAD. ${ }^{32} \mathrm{P}$ labelled proteins of a crude cell extract were precipitated with TCA, washed and incubated in $0.1 \mathrm{M}-\mathrm{KOH}$ at $27^{\circ} \mathrm{C}$ or $37^{\circ} \mathrm{C}$. Lane 1 , hydrolysis at $37^{\circ} \mathrm{C}$; lane 2 , at $27^{\circ} \mathrm{C}$. $\left(0.1 \mathrm{M}-\mathrm{KOH}\right.$ at $27^{\circ} \mathrm{C}$ or $\left.37^{\circ} \mathrm{C}\right)$, radioactivity was released. Analysis of the released products by TLC (Fig. 2) showed ADP-ribose and AMP at the lower temperature, but only AMP at the higher temperature. This hydrolysis pattern is typical for ADP-ribosylated proteins (Jouanneau et al., 1989). Thus, our results indicate that the labelled modifying group represents ADPribose. Accordingly, we suggest that the appearance of ADP-ribosylated proteins is age-dependent and, for some of them (especially the $44 \mathrm{kDa}$ protein), correlated with sporulation and antibiotic production.

\section{Correlation between the aba mutation and the altered phenotype}

The $a b a$ mutation leading to resistance to $3-\mathrm{ABA}$ was genetically analysed by the protoplast fusion technique. Auxotrophic aba mutants (arg $a b a-1$, pro $a b a-1$, and his $a b a-1)$ were derived from mutant 4 by chemical mutagenesis. Each auxotrophic $a b a$ mutant was crossed with the auxotrophic $a b a^{+}$strain (ura trp $a b a^{+}$), and then prototrophic recombinants that grew on minimum regeneration medium were analysed. In a cross between arg $a b a-1$ and ura trp $a b a^{+}$, all 38 prototrophic and 3ABA-resistant recombinants were defective at $30^{\circ} \mathrm{C}$ in streptomycin production, aerial mycelium formation, and submerged spore formation, while all $23 a b a^{+}$ recombinants tested exhibited the normal parental phenotype for these characteristics. Similar results were obtained in two other crosses (pro aba-1 $\times$ ura trp $a b a^{+}$, his $a b a-1 \times$ ura trp $\left.a b a^{+}\right)$. Furthermore, in four recombinants examined, those carrying the $a b a$ mutation exhibited 4-fold less ADPRT activity than did the $a b a^{+}$ strains. Thus, the $a b a$ mutation is tightly linked with all of the altered phenotypes.

We also attempted a reversion analysis by searching for revertants that could sporulate in nonselective media (lacking 3-ABA) at $30^{\circ} \mathrm{C}$. However, no strain $(<5 \times$ $\left.10^{-6}\right)$ with the parental phenotype was detected.

\section{Changes in nucleotide pool size}

From evidence obtained with several Streptomyces species, including $S$. griseus 13189, Ochi (1986a, b, $1987 a, b, 1990 a, b)$ proposed that morphological differentiation of Streptomyces results from a decrease in the GTP pool size, whereas physiological differentiation (e.g. antibiotic production) results more directly from a function of a rel gene affecting ppGpp accumulation. A recent study with Streptomyces antibioticus demonstrated that mRNA levels for phenoxazinone synthase, an enzyme involved in actinomycin synthesis, were much lower in a relC mutant than in the parent strain (Kelly et al., 1991). Therefore, we measured changes in nucleotide 
pools during growth at the non-permissive temperature. Mutant 4 displayed virtually the same pattern of nucleotide pool changes as reported for the parent strain (Ochi, 1987a). Furthermore, mutant 4 exhibited the normal parental ability to accumulate ppGpp [430 pmol (mg dry wt $)^{-1}$ ] during Casamino acid deprivation. Apparently, the effects of the aba mutation on $S$. griseus differentiation are not exerted through changes in the pool size of ppGpp or GTP.

To our knowledge, this is the first report of a possibly altered ADPRT; the system may be useful for studying the role of ADP-ribosylation in development and secondary metabolite production in Streptomyces. In particular, the conditional phenotype of mutant 4 may be useful. The reduced ADPRT activity in mutant 4, despite its normal parental phenotype at the permissive temperature, was unexpected. No explanation can be offered at present, but it may be that differentiation in $S$. griseus is initiated somewhat differently at $25^{\circ} \mathrm{C}$ and $30^{\circ} \mathrm{C}$. Alternatively, it might indicate that ADPRT activity has nothing to do with sporulation or streptomycin production. Some important questions to be answered are (i) whether the altered activity in ADPRT is caused directly by a lesion in the gene encoding the enzyme, and (ii) what role (if any) the $44 \mathrm{kDa}$ protein plays in promoting physiological and morphological differentiation. Whether $S$. griseus ADPRT exists in single or multiple forms should also be clarified.

\section{References}

Banasik, M., Komura, H., Shimoyama, M. \& Ueda, K. (1992). Specific inhibitors of poly(ADP-ribose) synthetase and mono(ADPribosyl)-transferase. Journal of Biological Chemistry 267, 1569-1575.

Barabas, Gy., Penyige, A., Szabo, I. \& Ensign, J. C. (1986). ADPribosylation in Streptomyces griseus. In Biological, Biochemical and Biomedical Aspects of Actinomycetes, pp. 827-829. Edited by G. Szabo, S. Biro \& M. Goodfellow. Budapest: Akademiai Kiado.

Barabas, Gy., Penyige, A., Szabo, I., Barabas, J. \& Ensign, J. C. (1988). Post-translational protein modification by ADP-ribosylation in Streptomyces. In Biology of Actinomycetes, pp. 439-444. Edited by Y. Okami, T. Beppu \& H. Ogawara. Tokyo: Japan Scientific Societies Press.

Edmonds, C., Griffin, E. G. \& Johnstone, A. P. (1989). Demonstration and partial characterization of ADP-ribosylation in Pseudomonas maltophilia. Biochemical Journal 261, 111-118.

Ferro, A. M., Higgins, N. P. \& Olivera, B. M. (1983). Poly(ADPribosylation) of a DNA topoisomerase. Journal of Biological Chemistry 258, 6000-6003.

HartmanN, A., Fu, H. \& BurRis, R. H. (1986). Regulation of nitrogenase activity by ammonium chloride in Azospirillum spp. Journal of Bacteriology 165, 864-870.

Jouanneau, Y., Roby, C., Meyer, C. M. \& Vignais, P. M. (1989). ADP-ribosylation of dinitrogenase reductase in Rhodobacter capsulatus. Biochemistry 28, 6524-6530.

KELLY, K. S., OCHI, K. \& JoNES, G. H. (1991). Pleiotropic effects of a relC mutation in Streptomyces antibioticus. Journal of Bacteriology 173, 2297-2300.

LAI, C.-Y. (1986). Bacterial protein toxins with latent ADP-ribosyltransferase activities. Advances in Enzymology 58, 99-139.

lucas, D. L., Tanuma, S. I., Davis, P. J. A., Wright, D. G. \& JoHnson, G. S. (1984). Maturation of human promyelocytic leukemia cells induced by nicotinamide : evidence of regulatory role for ADP-ribosylation of chromosomal proteins. Journal of Cellular Physiology 121, 334-340.

MiWA, M. \& SUgIMURA, T. (1990). ADP ribosylation and carcinogenesis. In ADP-ribosylating Toxins and G Proteins: Insights into Signal Transduction, pp. 543-560. Edited by J. Moss \& M. Vaughan. Washington, DC: American Society for Microbiology.

OCHI, K. (1986a). A decrease in GTP content is associated with aerial mycelium formation in Streptomyces MA406-A-1. Journal of General Microbiology 132, 299-305.

OCHI, K. (1986b). Occurrence of the stringent response in Streptomyces sp. and its significance for the initiation of morphological and physiological differentiation. Journal of General Microbiology 132, 2621-2631.

OCHI, K. (1987a). Metabolic initiation of differentiation and secondary metabolism by Streptomyces griseus: significance of the stringent response (ppGpp) and GTP content in relation to A-factor. Journal of Bacteriology 169, 3608-3616.

OCHI, K. $(1987 b)$. Changes in nucleotide pools during sporulation of Streptomyces griseus in submerged culture. Journal of General Microbiology 133, 2787-2795.

OCHI, K. (1990a). Streptomyces relC mutants with an altered ribosomal protein ST-L11 and genetic analysis of a Streptomyces griseus relC mutant. Journal of Bacteriology 172, 4008-4016.

$\mathrm{OCHI}, \mathrm{K}$. (1990b). A relaxed (rel) mutant of Streptomyces coelicolor A3(2) with a missing ribosomal protein lacks the ability to accumulate ppGpp, A-factor and prodigiosin. Journal of General Microbiology 136, 2405-2412.

Payne, D. M., Jacobson, E. L., Moss, J. \& Jacobson, M. K. (1985). Modification of proteins by mono(ADP-ribosylation) in vivo. Biochemistry 24, 7540-7549.

Penyige, A., Barabas, Gy., Szabo, I. \& Ensign, J. C. (1990). ADPribosylation of membrane proteins of Streptomyces griseus strain 521. FEMS Microbiology Letters 69, 293-298.

PoPe, M. R., ScotT, A. \& LudDEN, P. W. (1985). Covalent modification of the iron protein of nitrogenase from Rhodospirillum rubrum by adenosine diphosphoribosylation of a specific arginine residue. Proceedings of the National Academy of Sciences of the United States of America 82, 3173-3177.

Purnell, M. R. \& Whish, W. J. D. (1980). Novel inhibitors of poly(ADP-ribose) synthetase. Biochemical Journal 185, 775-777.

SKoRKo, R. (1982). T4 and N4 phage-encoded ADP-ribosyltransferase. In ADP-ribosylation Reactions, pp. 647-694. Edited by O. Hayaishi \& K. Ueda. New York: Academic Press.

Tanigawa, Y., Tsuchiya, M., Imai, Y. \& Shimoyama, M. (1983), ADP-ribosylation regulates the phosphorylation of histones by the catalytic subunit of cyclic AMP-dependent protein kinase. FEBS Letters 160, 217-220.

UEDA, K. \& HAYAISHI, O. (1985). ADP-ribosylation. Annual Review of Biochemistry 54, 73-100. 